\title{
THE DEVELOPMENT OF E-COMMERCE AND CONSUMER ATTITUDES - A COMPARATIVE ANALYSIS OF POLAND, UKRAINE AND BELARUS
}

\author{
Prof. Bogdan Gregor ${ }^{1}$ \\ Magdalena Kalińska-Kula, Ph.D., Associate Professor ${ }^{2}$ \\ University of Lodz \\ Faculty of Management \\ Department of Marketing \\ Matejki 22/26, 90-237 Lodz, Poland \\ 1e-mail:km.wz@uni.lodz.pl \\ ORCID: 0000-0003-1681-2073 \\ ${ }^{2}$ e-mail: magdalena.kalinska@uni.lodz.pl \\ ORCID: 0000-0003-4809-1901
}

Received 16 January 2020, Accepted 20 March 2020

\begin{abstract}
Research background: Motivation for this paper is the rapid development of the electronic commerce sector and its increasing role as a sales channel. The level of e-commerce development is spatially diverse, both across continents and countries. As such, this study examined the conditions of electronic commerce development in the context of the specificity of e-consumers' behavior in selected European countries.

Purpose: The purpose of the paper is to compare the attitudes towards e-commerce among buyers from Poland, Ukraine and Belarus along with their activities directly related to online shopping.

Research methodology: The paper focuses on the results of a study conducted in central and eastern European countries on a sample of nearly 1,000 respondents. The statistical tools used included the KruskalWallis test and an independence analysis through SPSS v. 25 and Statistica v. 13.3.

Results: The results showed that the country of origin is a variable differentiating both activities connected with shopping online undertaken by e-consumers and buyers' attitudes towards e-commerce in the context of such aspects as: safety, convenience, time-consuming, possibilities of choice, ease and the economics of shopping. The predominant dependence between the country of origin of respondents and their inclination to use the Internet has not been confirmed.
\end{abstract}

Novelty: The study contributes to the on-going and extremely current issue of the importance of e-commerce and the conditions of its development.

Keywords: online shopping, e-consumers' attitudes, e-commerce 


\section{Introduction}

Less than a decade ago e-commerce accounted for only a small fraction of retailing whereas nowadays, due to the increasing availability of Internet access, the number of online shops increases year by year and so does the number of people shopping online. Numerous publications are a reflection of the growing interest of the world of science in this extremely current issue regarding the significance of e-commerce, and this paper is one of them. The available literature presents studies on the behavior of market participants (including individual consumers) in the e-commerce sector, but the issue has not yet been recognized in a comprehensive manner in the scope of the subject matter as well as the spatial one (in Europe and globally).

Tremendous progress in information and telecommunication technologies along with the popularization of the Internet have become a driving force for a dynamically developing electronic commerce sector. Factors conducive to e-commerce development include also a significant increase in the average speed of Internet connections and bigger and bigger Internet content.

Modern consumers expect increasing flexibility in access to products and services and freedom in making decisions in terms of the choice of a purchasing channel (Gregor, GotwaldFeja, Łaszkiewicz, 2017), and e-commerce enables gaining benefits desired by buyers. Online shopping is nowadays such a popular form of buying various goods and services that many enterprises dealing with traditional trade decide to diversify their activity and start setting up electronic trade counting on increasing revenues (de Pourbaix, 2013). Online buyers find that form of shopping easy and convenient, and additionally offering more opportunities of choice than buying in traditional shops (Bartczak, 2016).

The level of e-commerce development - like the development of the Internet - is spatially diverse, both across continents and countries within a given continent. This is mainly due to not only economic conditions but also cultural, regulatory and infrastructural ones. The factors necessary for e-commerce development include: widespread Internet access, a network of online shops, appropriate procedures connected with placing orders, payments and delivery as well as logistics infrastructure (Gregor et al., 2017). International comparative studies undertaken to supplement, systematize, deepen and verify knowledge of the behavior of market participants, including consumers, are one of the important areas of economic research.

The main purpose of the paper is to analyze the diversity of the level of development of e-commerce as well as the attitudes and purchasing behavior of e-consumers across the three countries covered by the study: Polish, Ukraine and Belarus. Specific objectives, among others, comprised: 
- the identification of the popularization of the Internet among respondents from the examined countries,

- determination of dependence between features such as age, sex, place of residence, financial situation and the country of origin of respondents and their inclination to use the Internet,

- determination of the activities connected with online shopping performed by respondents on the Internet across the examined countries,

- the identification of the differences in buyers' attitudes and opinions regarding electronic commerce in the countries covered by the study,

- determination of the perspectives for the development of e-commerce in the coming years.

Against the background of the adopted objectives the following research hypotheses were formulated:

(H1) dependence between the country of origin of the respondents and their inclination to use the Internet is stronger than in the case of other variables i.e. sex, age, place of residence or financial situation;

(H2) the country of origin differentiates the activity of the Internet users in terms of undertaken activities connected with buying online;

(H3) the country of origin is a variable that differentiates attitudes of buyers towards e-commerce.

The paper presents a literature review on the context of e-commerce development and the popularization of the Internet. The research section presents the results of the cross-national analysis. The last part contains the conclusions.

\section{Development of e-commerce against the background of the popularization of the Internet}

Currently there are over 1.5 billion websites, which means almost seven-times growth within the last ten years (from 238 million in 2009 to 1.6 billion in 2019) (Internet Live Stats, 2019). ${ }^{1}$ About 4.5 billion people have Internet access, ${ }^{2}$ so it is almost two and a half times more than ten years ago (1.8 billion in 2009). In the last decade the number of Internet users has

\footnotetext{
1 Changes in online statistics, including the number of users in the world and the number of websites that can be tracked on an ongoing basis at www.internetlifestats.com.

24.3 billion according to www.internetlifestats.com, 4.5 billion according to www.internetworldstats.com (29.09.2019)
} 
increased annually by $15 \%$. The Internet penetration rate rose in that period from 25.8 to $57 \%$ (Internet Live Stats, 2019).

In this respect the situation differs across individual continents. The biggest group of people with Internet access are inhabitants of Asia whose number in June 2019 amounted to 2.3 billion, which accounted for half of the total number of Internet users in the world. However, the Internet penetration rate on this continent is lower than the world average $(54.2 \%$ and $58.8 \%$ respectively). The second place in terms of a number of Internet users belongs to Europe, where 727 million people have access to the Internet $(16 \%$ of the total number of Internet users in the world), which accounts for over $87.7 \%$ of its whole population. Yet, the highest Internet penetration rate $-89.4 \%$ was noted in North America where 328 million people have access to the Internet ( $7.2 \%$ of the total number of Internet users in the world). Notably, the dynamically developing Internet can be observed on the African continent where the number of Internet users in June 2019 amounted to 523 million (11.5\% of the whole Internet) although the Internet penetration rate is still the lowest there (39.6\%). Taking into consideration individual countries, in 2019 the biggest number of Internet users lived in China - 854 million (Internet penetration rate of $60.1 \%$ ), India - 560 million (40.9\%) and the USA - 293 million (89\%) (Internet World Stats, 2019).

Among European countries the biggest number of people with Internet access lived in Russia - 109 million (Internet penetration rate - 76.1\%), in Germany - 79 million (96\%), Turkey - 69 million (83.3\%) and France - 60 million (92.3\%). The number of Internet users in Poland amounted to almost 30 million (increase by $76.4 \%$ compared to 2014), and a penetration rate $-78.2 \%$, in Ukraine it was 41 million (93.4\%), and in Belarus 7 million (74.4\%) (Internet World Stats, 2019).

The development of the Internet and its growing penetration are driving forces of high dynamics of e-commerce turnover (Jasiński, 2016). In 2018 about 1.8 billion people in the world bought goods and services online and according to forecasts, in 2021 more than 2.14 billion people will buy online (statista.com, 2019). In terms of value global e-retailing increased from $\$ 1.23$ trillion in 2013 to $\$ 3.53$ trillion in 2019 , which means almost a 3-fold increase. According to forecasts revenues this trade will rise to \$6.54 trillion in 2023 (Lipsman, 2019).

The value of the European e-commerce channel amounted to EUR 602 billion at the end of 2018, which means almost a two-fold growth compared to 2013 . Nearly $60 \%$ of turnover is generated by three markets: the British, French, German and the share of Poland is 2\% (Cushman, Wakefield, 2019). Nearly $74 \%$ of internet users worldwide admitted having bought something online in the last month (data for Q3 2019), 80\% visited an online retail store, and 
90\% searched online for products or services that they intended to buy (Digital 2020 Global Overview Report, 2020). Online shopping has become such a common form of purchasing various goods and services, also because in comparison to the traditional trade e-commerce has some advantages over a number of different aspects relevant to consumers.

Online shopping is mainly related to convenience (purchase without leaving home), the possibility of quiet reflection on the purchase and being able to compare many offers (Bartczak, 2016). Among the advantages of e-commerce there is also a greater choice of offers from all over the world, the possibility of buying hard-to-reach goods and niche products, with virtually unlimited availability ( 24 hours, 7 days a week, 365 days a year), the possibility of getting acquainted with the offer without time limits and pressure from the seller, the possibility of comparing competitive offers and obtaining a lower price (in comparison with the prices of the same goods in traditional stores) (Barska, 2013). In the light of the research results, the most important factors that are motivating for online shopping include: lower price of the offered products, time savings, a large selection of products and the ability to compare many offers in terms of price and technical parameters (Jaciow, Wolny, 2011). This is confirmed by the results of subsequent studies, according to which the most important driving forces of online shopping are: convenience and time saving, lower prices, wider selection and easy comparison of offers from various sellers, as well as the opportunity to meet other users reviews (Gracz, Ostrowska, 2014).

In addition to the factors favoring online shopping, also the demotivating factors should be mentioned, which are primarily concerns resulting from the risks perceived by the buyer and associated with the online shopping. Customers' own experiences, learned from previous activities, play an important role in shaping consumer behavior. The reasons for dissatisfaction with online purchases include: the poor quality of the purchased goods, long delivery time and product non-compliance with the description. E-customers also mention problems such as: improper size of the purchased product, unrealized order, improper customer service and goods damaged during transport, issues related to the warranty, return or complaint (Gracz, Ostrowska, 2014). The indicated restrictions may discourage customers from buying online, although positive experiences and satisfaction with previous transactions would minimize the risk perceived by the consumer (Pires, Stanton, Eckford, 2004).

The e-commerce market in Poland is still extremely dynamic. On average, 21 new online shops appear every day and their total number in 2019 amounted to over 30 thousand (E-Commerce $w$ Polsce, 2019). At the end of 2018 the value of Polish e-commerce reached PLN 51 billion (almost a 5-fold increase in the last 10 years), and online shopping was used 
by 28 million Poles (Cushman, Wakefield, 2019). According to studies by Gemius company, in 2019 nearly two thirds (62\%) of the examined Internet users buy online, which means a 6\% growth compared to the previous year (E-Commerce $w$ Polsce, 2019). In the literature on the subject one can find a series of publications describing the profile of Polish e-consumer, the product structure of their shopping basket or motives for buying online (inter alia, in Gracz, Ostrowska, 2014; Jaciow, Wolny 2011; Lewicki, 2018; Pacut, 2016; Skorupska, 2017; Wołoszyn, Stanisławska, 2016). Online buyers are representatives of all age groups, people of different education levels, with a slight prevalence of people below 50 with higher education and declaring a positive assessment of their financial status. The most popular categories of products purchased online include clothes, accessories, shoes, books, CDs, films as well as cosmetics/perfumes (E-Commerce w Polsce, 2019).

Belarus is a country outside the European Union and nowadays technological progress and access to the Internet is slightly delayed there compared to Western European countries although the situation has been improving in recent years. The development of an information society is perceived as one of the main factors determining competitiveness, innovation and a civil society (Стратегия развития информатизации, 2015). Before 2016 there were above 120 thousand domains registered in Belarus (Стратегия развития информатизации, 2015), and currently more than three quarters of the population use the Internet (Internet World Stats, 2019). New websites appear every day, and an increasing number of small and big companies are starting online activities. Among the factors contributing to Internet development in Belarus we can mention reduction of fees for data transmission and the unification of pricing for entrepreneurs and natural persons. What was of crucial importance was also the issuing of decree no 60 by the President of Belarus concerning regulatory frameworks supporting the development of the domestic Internet sector (Указ Президента Республики Беларусь, 2010), which nearly doubled the market of websites. However, the factors that hinder the development of informatization in Belarus include, among others, low efficiency of government authorities in solving information problems, lack of motivation to change business processes indispensable to implement information-communication technologies, insufficient level of investments in ICT, weak use of public-private partnership including the area of science and research (Стратегия развития информатизации, 2015).

According to statistics, nowadays over 40 million people living in Ukraine use the Internet (Internet World Stats, 2019), and a number of active users of social media amounts to 13 million (Digital 2018 Global Overview Report, 2018). According to studies, 36\% of Internet users buy products online on a regular basis and e-consumers are usually people with higher education 
between 26-35, men and women in equal proportions with a middle level of income (gfk. com, 2018). More than a half of consumers prefer to buy by means of mobile applications and leading shopping websites in Ukraine are OLX and AliExpress. The products that are most frequently bought online include household equipment, computer equipment, electronics, clothes, cosmetics and perfumes, and while choosing a specific e-shop consumers generally pay attention to the following things: price, positive shopping experience at this website, and availability of a desired product (gfk.com, 2018).

\section{Research methodology}

In the period between 2017-2019 at the University of Łódź Department of Marketing an international research project that was entitled Behavior of buyers and sellers in the e-commerce sector ${ }^{3}$ was conducted. The aim of the project was, inter alia, to determine the role and perspectives of electronic commerce development by collecting opinions on its conditions in selected European countries. The range of conducted studies was much wider, however, due to the limited size of this paper, only selected issues, directly connected with the presented topic were included.

The paper focuses on the analysis of the results of a study conducted in 3 central and eastern European countries on a sample of 997 respondents, including 536 people in Poland, 247 in Ukraine and 214 in Belarus (the sample structure is presented in Table 1). Research proceedings focused on a group of young consumers below 25 who today represent a significant proportion of online buyers and in the perspective of the coming years they will become an increasingly important segment of online commerce.

Respondents for the sample were selected in a convenient way. The research methods were a class and direct survey and the measurement tool was a questionnaire. A quantitative study was chosen because it was necessary to verify statistically the hypotheses formulated by the researchers. The purpose of the study was to present descriptive conclusions that would allow verifying the current picture of the studied phenomena (Czakon, 2015). Due to the subject of the study, especially the nature of the acquired data, it was decided to use a questionnaire as a measurement instrument. The reasons for choosing the survey techniques were mainly: a large sample, its considerable dispersion in space and relatively low research costs. The purpose of the research procedure was also to provide the respondents with comfort and a sense of anonymity.

\footnotetext{
3 Partial results of studies were published in scientific articles: Gregor, Kalińska-Kula (2018b), pp. 138-148; Gregor, Kalińska-Kula (2018a), pp. 110-120.
} 
The prevailing majority of respondents were people below 25 (over 60\%) living in big cities - over 500 thousand residents (slightly over one third of respondents), generally declaring an average financial situation (nearly half of respondents), both women (almost 65\%) and men (over 35\%).

Table 1. Characteristics of the research sample (structure in percent)

\begin{tabular}{|c|c|c|c|c|c|}
\hline & Demographic features & Poland & Belarus & Ukraine & Total \\
\hline \multirow{2}{*}{ Sex } & women & 57.3 & 76.6 & 71.3 & 64.9 \\
\hline & men & 42.7 & 23.4 & 28.7 & 35.1 \\
\hline \multirow{5}{*}{ Age } & between $17-24$ & 59.1 & 84.6 & 41.7 & 60.3 \\
\hline & between $25-34$ & 15.9 & 2.8 & 19.4 & 13.9 \\
\hline & between $35-44$ & 10.3 & 0.9 & 14.2 & 9.2 \\
\hline & between $45-54$ & 8.0 & 5.1 & 15.4 & 9.2 \\
\hline & 55 and older & 6.7 & 6.5 & 9.3 & 7.3 \\
\hline \multirow{6}{*}{$\begin{array}{l}\text { Size of place } \\
\text { of residence }\end{array}$} & countryside & 25.9 & 16.4 & 19.4 & 22.3 \\
\hline & up to 20,000 residents & 14.6 & 13.1 & 2.8 & 11.3 \\
\hline & between $20-50,000$ residents & 11.9 & 7.9 & 4.0 & 9.1 \\
\hline & between $50-200,000$ residents & 10.6 & 15.9 & 3.6 & 10.0 \\
\hline & between $200-500,000$ residents & 4.1 & 19.6 & 11.3 & 9.2 \\
\hline & over 500,000 residents & 32.8 & 27.1 & 58.7 & 38.0 \\
\hline \multirow{5}{*}{$\begin{array}{l}\text { Household } \\
\text { material situation }\end{array}$} & very bad & 0.7 & 3.3 & 4.9 & 2.3 \\
\hline & bad & 6.5 & 11.2 & 16.6 & 10.0 \\
\hline & average & 27.4 & 80.4 & 68.0 & 48.8 \\
\hline & good & 53.7 & 4.2 & 7.3 & 31.6 \\
\hline & very god & 11.6 & 0.9 & 3.2 & 7.2 \\
\hline \multicolumn{2}{|l|}{ Total } & 53.8 & 21.5 & 24.8 & 100.0 \\
\hline
\end{tabular}

Source: own elaboration.

In order to verify the hypotheses the non-parametric Kruskal-Wallis test was used due to the fact that the obtained distributions of values of dependent variables deviate from a normal distribution (verification by means of the Kołmogorow-Smirnow test), and additionally part of the dependent variables were measured on an ordinal scale. For country-by-country comparisons the multiple post-hoc comparisons for the mean ranks were used (two-tailed test with Bonferroni correction for each pair compared). The statistical significance of the relationship between variables was determined on the basis of the chi-square test of independence that can be used for various samples identified in terms of nominal features (Mynarski, 2003), whereas 
the strength of relationship was measured by means of the Cramer's $V$ coefficient (Malarska, 2005). In the course of the conducted analyses all necessary calculations were performed by means of the SPSS software for Windows (version 25.0) and Statistica (version 13.3).

While interpreting the presented results the limitations of the study should be taken into consideration. Due to the non-random selection of the sample and differences in sizes of the examined groups, the results cannot be considered as fully representative for the whole population. The cautions with the interpretation of the findings also results from the use of the Kruskal-Wallis test, because of the greater likelihood of making type I and type II errors in comparison to parametric ANOVA.

\section{Results}

The initial cognitive objective of the study was to determine the degree of Internet popularization among the respondents representing various countries. Moreover, various groups were differentiated according to such features as age, sex, size of place of residence and financial situation.

In the group of 997 respondents $93.4 \%$ admitted that they use the Internet, and the biggest proportion of such people was noted among respondents from Poland (95.7\%), a smaller group in Belarus (88.8\%), and the smallest in Ukraine (84.2\%). The indicated dependence between the country of origin of the respondents and their inclination to use the Internet was statistically significant $\chi^{2}(2, \mathrm{~N}=997)=30.68 ; \mathrm{p}<0.001$ of a low strength of relationship (Cramer's $V$ coefficient $=0.175)$. It is worth stressing that in the case of the variable of respondents' age statistically significant dependence $\chi^{2}(4, \mathrm{~N}=997)=347.15 ; \mathrm{p}<0.001$ of high strength of relationship was observed (Cramer's $V$ coefficient $=0.590)$, and the lowest proportion of people using the Internet was noted in a group of the oldest respondents -55 or older $(41.1 \%)$, slightly higher in the group of people between 45-54 (69.6\%), in the group of people between 35-44 it was every ninth respondent $(90.2 \%$ ) and the highest proportions (above $99 \%$ ) were noted in groups between 25-34 and 17-24. A statistically significant dependence of an average strength of relationship was also observed in the case of the declared financial situation of respondents: $\chi^{2}(4, \mathrm{~N}=997)=99.91 ; \mathrm{p}<0.001($ Cramer's $V$ coefficient $=0.317)$ where in the case of people recognizing their material situation as very good or good, the proportion of Internet users was very high (98.6\% and 97.8\% respectively), and significantly lower among respondents declaring a very bad financial situation (43.5\%). Statistically significant dependence, albeit of weak strength of relationship, was noted also in the case of the place of residence variable: 
$\chi^{2}(5, \mathrm{~N}=997)=55.79 ; \mathrm{p}<0.001($ Cramer's $V$ coefficient $=0.237)$ where a smaller proportion of people using the Internet was observed among respondents living in rural areas $(82.0 \%)$ and the highest in the case of residents of cities of over 500 thousand residents $(97.9 \%)$. No statistically significant relationship was noted in the case of the sex variable.

One of the objectives of the study was to determine what activities are conducted while buying online as well as to examine whether there are differences in the range of the frequency of undertaken activities among people representing individual countries. In the course of the study such activities were considered as: looking for products or brands that a respondent wants to buy as well as shops that they want to visit; comparing prices; buying products and services. Respondents gave answers according to an ordinal scale: on a regular basis (i.e. every day) -5 , often (a few times a week but not less frequently than once a week) -4 , sometimes (a few times a month but not less frequently than once a month - 3, seldom (less frequently than once a month but at least once a year) -2 , never -1 .

In the group of all examined Internet users nearly one in every nine searched online for products that they intended to buy $(85.4 \%$ - which accounts for a proportion of total number of answers of "on a regular basis", "often" or "sometimes"), and a slightly lower proportion of people compare prices on the internet $(81.2 \%)$. Nearly three in every four respondents buy online (72.4\%), and slightly more than a half look for shops they want to visit online $(60.2 \%)$.

Table 2 presents the results of the analysis concerning activities conducted online by the respondents. It was found that there were a number of statistically significant differences across the compared countries.

Table 2. Differentiation of activities undertaken by Internet users in connection with buying online in a division related to a country of respondents' origin

\begin{tabular}{|c|c|c|c|c|c|c|}
\hline \multirow{2}{*}{ Type of activity } & \multirow{2}{*}{ Country } & \multirow{2}{*}{$\mathrm{N}$} & \multirow{2}{*}{ Median } & \multirow{2}{*}{$\begin{array}{l}\text { Average } \\
\text { rank }\end{array}$} & \multicolumn{2}{|c|}{ Kruskal-Wallis test } \\
\hline & & & & & $\mathrm{H}$ & $\mathrm{p}$ \\
\hline 1 & 2 & 3 & 4 & 5 & 6 & 7 \\
\hline \multirow{3}{*}{ Looking for products/brands } & Poland & 513 & 4 & 515.72 & \multirow{3}{*}{74.38} & \multirow{3}{*}{$<0.001$} \\
\hline & Belarus & 190 & 3 & 342.41 & & \\
\hline & Ukraine & 208 & 3 & 412.46 & & \\
\hline \multirow{3}{*}{$\begin{array}{l}\text { Looking for shops that a buyer } \\
\text { wants to visit }\end{array}$} & Poland & 513 & 3 & 496.08 & \multirow{3}{*}{29.72} & \multirow{3}{*}{$<0.001$} \\
\hline & Belarus & 190 & 3 & 400.60 & & \\
\hline & Ukraine & 208 & 2 & 407.77 & & \\
\hline \multirow{3}{*}{$\begin{array}{l}\text { Comparing the prices of products/ } \\
\text { services }\end{array}$} & Poland & 513 & 4 & 499.88 & \multirow{3}{*}{36.64} & \multirow{3}{*}{$<0.001$} \\
\hline & Belarus & 190 & 3 & 386.48 & & \\
\hline & Ukraine & 208 & 3 & 411.29 & & \\
\hline
\end{tabular}




\begin{tabular}{|c|c|c|c|c|c|c|}
\hline 1 & 2 & 3 & 4 & 5 & 6 & 7 \\
\hline \multirow{3}{*}{ Buying products/services } & Poland & 513 & 3 & 509.90 & \multirow{3}{*}{81.75} & \multirow{3}{*}{$<0.001$} \\
\hline & Belarus & 190 & 3 & 315.16 & & \\
\hline & Ukraine & 208 & 3 & 451.72 & & \\
\hline
\end{tabular}

Source: own elaboration.

The differences among the studied groups for looking for products or brands were statistically significant. Multiple comparisons showed that the declared frequency of this type of activity was higher for respondents in Poland than in Ukraine $(p<0.001)$ and Belarus $(p<0.001)$, and in Ukraine than in Belarus $(p<0.05)$. Similar statistically significant differences were depicted for: looking for shops that a buyer wants to visit - much more frequently in Poland than in Ukraine $(\mathrm{p}<0.001)$ and Belarus $(\mathrm{p}<0.001)$, comparably in Ukraine and Belarus; comparing prices more frequently in Poland, less frequently in Ukraine $(\mathrm{p}<0.001)$ and in Belarus $(\mathrm{p}<0.001)$, comparably in Ukraine and Belarus; doing online shopping - more frequently in Poland, less frequently in Ukraine $(\mathrm{p}<0.001)$ and in Belarus $(\mathrm{p}<0.05)$, and significantly more often in Ukraine than in Belarus $(\mathrm{p}<0.001)$.

A significant cognitive objective of the study was to identify the attitudes of buyers towards e-commerce with a particular focus on differences in the attitudes of buyers from individual countries. In the light of the results the vast majority of respondents, as much as $90.2 \%$ declared doing online shopping. Nearly three quarters of all respondents buy online "on a regular basis", "often" or "sometimes" whereas $17.8 \%$ do it "seldom" and nearly one in ten respondents $(9.8 \%)$ admitted that they never bought anything online.

It is worth noting that in the case of the examined variables: country of origin of the respondents and buying online, a statistically significant dependence was noted e $\chi^{2}$ $(8, \mathrm{~N}=911)=94.34 ; \mathrm{p}<0.001$ of average strength of relationship (Cramer's $V$ coefficient $=$ 0.228 ), whereas in the light of earlier presented results analyzed by means of the Kruskal-Wallis test $(\mathrm{H}(2, \mathrm{~N}=911)=81.75 ; \mathrm{p}<0.001)$ it was confirmed that the difference in distributions is statistically significant and declared frequency of shopping online is higher in the case of respondents in Poland than in Ukraine and Belarus.

In the course of further analyses a group of 822 respondents was in focus who confirmed that they had done shopping online before. They were asked to comment on a series of statements concerning shopping online, including such issues as: safety, ease of shopping, economics of shopping, duration and convenience as well as possibilities of choice. The measurement was conducted by means of a semantic scale describing opposite poles by means of opposite 
statements and assigning them weights from 1 to 5 where a higher weight meant a more positive assessment. The results of the analysis are presented below in Table 3 .

Table 3. Respondents' opinions on buying online - differentiation of average ranks from opinions given by respondents in a division in relation to their country of origin $(\mathrm{N}=822)$

\begin{tabular}{|c|c|c|c|c|c|c|c|}
\hline \multirow{2}{*}{ Online shopping } & \multirow{2}{*}{ Country } & \multirow{2}{*}{$\mathrm{N}$} & \multirow{2}{*}{ M } & \multirow{2}{*}{$\mathrm{SD}$} & \multirow{2}{*}{$\begin{array}{l}\text { Average } \\
\text { rank }\end{array}$} & \multicolumn{2}{|c|}{ Kruskal-Wallis test } \\
\hline & & & & & & $\mathrm{H}$ & $\mathrm{p}$ \\
\hline \multirow{3}{*}{ Is safe (5)/risky (1) } & Poland & 485 & 3.62 & 0.87 & 455.23 & \multirow{3}{*}{51.67} & \multirow{3}{*}{$<0.001$} \\
\hline & Belarus & 149 & 3.04 & 0.87 & 314.68 & & \\
\hline & Ukraine & 188 & 3.31 & 0.93 & 375.43 & & \\
\hline \multirow{3}{*}{ Is easy (5)/difficult (1) } & Poland & 485 & 4.40 & 0.77 & 445.72 & \multirow{3}{*}{29.16} & \multirow{3}{*}{$<0.001$} \\
\hline & Belarus & 149 & 4.07 & 0.89 & 359.47 & & \\
\hline & Ukraine & 188 & 4.08 & 0.92 & 364.46 & & \\
\hline \multirow{3}{*}{$\begin{array}{l}\text { Is cheaper ( } 5) / \text { more expensive ( } 1) \\
\text { than buying in traditional shops }\end{array}$} & Poland & 485 & 4.01 & 0.92 & 434.96 & \multirow{3}{*}{14.76} & \multirow{3}{*}{$<0.01$} \\
\hline & Belarus & 149 & 3.75 & 0.87 & 358.76 & & \\
\hline & Ukraine & 188 & 3.87 & 0.89 & 392.77 & & \\
\hline \multirow{3}{*}{$\begin{array}{l}\text { Takes less }(5) / \text { more }(1) \text { time than } \\
\text { buying in traditional shops }\end{array}$} & Poland & 485 & 4.27 & 0.92 & 447.78 & \multirow{3}{*}{32.57} & \multirow{3}{*}{$<0.001$} \\
\hline & Belarus & 149 & 3.85 & 0.97 & 345.68 & & \\
\hline & Ukraine & 188 & 3.91 & 1.07 & 370.06 & & \\
\hline \multirow{3}{*}{ Is convenient (5)/cumbersome (1) } & Poland & 485 & 4.50 & 0.77 & 453.56 & \multirow{3}{*}{46.64} & \multirow{3}{*}{$<0.001$} \\
\hline & Belarus & 149 & 4.11 & 0.99 & 362.28 & & \\
\hline & Ukraine & 188 & 4.04 & 0.97 & 342.01 & & \\
\hline \multirow{3}{*}{$\begin{array}{l}\text { Creates more }(5) / \text { less (1) possibilities } \\
\text { of choice than traditional shops }\end{array}$} & Poland & 485 & 4.27 & 0.87 & 449.24 & \multirow{3}{*}{34.26} & \multirow{3}{*}{$<0.001$} \\
\hline & Belarus & 149 & 3.88 & 0.94 & 350.02 & & \\
\hline & Ukraine & 188 & 3.95 & 0.89 & 362.87 & & \\
\hline
\end{tabular}

Source: own elaboration.

On the basis of the results of the analysis, it was determined that the most positive opinions on the presented statements concerning e-commerce were expressed by respondents from Poland. The observed differences across countries are statistically significant in all examined aspects. Therefore, it can be assumed that the country of origin is a variable differentiating the attitudes of buyers towards e-commerce.

All respondents highly assessed an aspect of the convenience of online shopping (average of all marks of respondents $M=4.32 ; S D=0.88$ ), and multiple comparisons showed that respondents' marks were explicitly higher in the case of respondents in Poland than in Belarus $(\mathrm{p}<0.001)$ and Ukraine $(\mathrm{p}<0.001)$, while comparably in Ukraine and Belarus. Relatively highly assessed were also aspects such as: ease of shopping online $(M=4.27 ; S D=0.84)$, possibilities 
of the choice of products $(M=4.13 ; S D=0.91)$ and less time needed to buy online $(M=4.11$; $S D=0.98$ ). Multiple comparisons indicated that respondents' opinions were markedly higher than in the case of respondents from Poland than in Ukraine $(p<0.001)$ and Belarus $(p<0.001)$, and at a comparable level in Ukraine and Belarus.

Concerning online shopping economics assessments $(M=3.93 ; S D=0.91)$ differed less noticeably between groups and the highest were observed among respondents in Poland. Multiple comparisons have showed that the respondents' opinions were higher in Poland than in Belarus ( $<<0.01)$, while comparable in Poland and Ukraine, as well as in Belarus and Ukraine. As far as opinions on the safety of online shopping are concerned, they were moderately positive $(M=3.44 ; S D=0.91)$ and comparisons showed that assessments of respondents in Poland were considerably higher than in Ukraine $(\mathrm{p}<0.001)$ and Belarus $(\mathrm{p}<0.001)$, while comparable in Belarus and Ukraine.

All respondents were asked how the role of e-commerce will change in the next 3-5 years. All respondents expressed positive opinions on the examined issue, however with the highest percentage of opinions that e-commerce will increase rapidly was recorded in the case of respondents in Belarus (40.3\%), and comparable in Poland and Ukraine (39.0\%). While, the highest percentage of opinions that e-commerce will gradually increase was recorded among respondents in Poland (over half of the respondents), lower in Ukraine (two out of five respondents) and in Belarus (just over a third of respondents). The indicated dependence was statistically significant $\chi^{2}(10, \mathrm{~N}=997)=56.53 ; \mathrm{p}<0.001$ of the low strength of relationship $($ Cramer's $V$ coefficient $=0.168)$.

\section{Conclusions}

The presented discussion confirmed the rapid development of e-commerce and increase of its role as a sales channel, which is a consequence of growing Internet penetration and increasing number of consumers convinced about buying online. Shopping that way becomes for consumers markedly easier, faster and safer. At the same time, the e-consumer is influenced by a number of factors, including macroeconomic conditions: political, legal, economic, social, cultural, technological and international (Thomas, 1999; Światowy, 2006) as well as demographic and geographical factors (including age, gender, place of residence) (Kieżel, 1995). Consumer behavior changes, especially in the aspect of searching for information about products, as well as places and methods of purchasing, were radically affected by the development of the Internet (Linkiewicz, Bartosik-Purgat, 2017). 
While analyzing a degree of Internet popularization among respondents representing the countries surveyed, it was observed that the highest proportion among respondents is noticed in Poland, lower in Belarus and the lowest in Ukraine. That dependence was statistically significant, yet, a stronger relationship was noted in the case of such variables as: age (the strongest dependence), financial situation and place of residence, so the hypothesis stating that dependence between the country of origin of respondents and their inclination to use the Internet is stronger than in the case of other variables has not been confirmed.

The results of the presented tests confirmed a statistically significant differentiation of activities connected with shopping online among respondents representing the surveyed countries, so the hypothesis stating that the country of origin diversifies the activities undertaken by the Internet users in this regard has been confirmed.

The analysis of attitudes of buyers representing various countries in terms of e-commerce in the context of such aspects as: safety, ease of shopping, economics of shopping, duration of time needed, convenience as well as possibilities of choice - indicated that the most positive opinions on online shopping were expressed by respondents from Poland. Statistically significant differences were observed in all examined aspects, but it should be noted that the expressed opinions differed significantly in the case of respondents from Poland in comparison to other countries' respondents, while they remained at a comparable level in Ukraine and Belarus. The hypothesis stating that the country is a variable differentiating the attitudes of consumers towards e-commerce has been confirmed.

All respondents expressed positively about how the role of e-commerce would change in the next 3-5 years, however the highest percentage of opinions that e-commerce would increase rapidly was noted in Belarus and Ukraine, therefore in countries where Internet popularization was relatively lower than in Poland. On the other hand, among the respondents from Poland, where the highest percentage of people confirmed using of the Internet, the opinions prevailed that e-commerce will increase gradually.

The presented conclusions may constitute a basis for further deepened analyses in terms of international socio-cultural differences and their impact on the attitudes and behavior of e-buyers. 


\section{References}

Barska, A. (2013). Stan i perspektywy rozwoju ehandlu w Polsce. Zeszyty Naukowe Uniwersytetu Szczecińskiego, 776 (31), 11-22.

Bartczak, K. (2016). Bariery rozwojowe handlu elektronicznego. Wrocław: Wydawnictwo Exante.

Cushman, Wakefield (2019). How to bite e-commerce in a warehouse. Retrieved from: http:// info.cushmanwakefield.com/1/263412/2019-06-12/yvgkq.

Czakon, W. (2015). Podstawy metodologii badań w naukach o zarzadzaniu. Warszawa: Oficyna a Wolters Kluwer business.

de Pourbaix, P. (2013). Internet jako kanał dystrybucji. Handel Wewnętrzny, 3, 1-12.

Gemius, Izba Gospodarki Elektronicznej (2019). E-Commerce w Polsce 2019. Gemius dla e-Commerce Polska. Retrieved from: https://www.gemius.pl/wszystkie-artykuly-aktualnosci/ najnowsze-dane-o-polskim-e-commerce-juz-dostepne.html.

Gracz, L., Ostrowska, I. (2014). Młodzi nabywcy na e-zakupach. Warszawa: Wydawnictwo Placet.

Gregor, B., Gotwald-Feja, B., Łaszkiewicz, A. (2017). E-commerce a zachowania konsumentów. In: M. Bartosik-Purgat (ed.), Zachowania konsumentów. Globalizacja, nowe technologie, aktualne trendy, otoczenie spoleczno-kulturowe (pp. 99-126). Warszawa: Wydawnictwo Naukowe PWN

Gregor, B., Kalińska-Kula, M. (2018a). Rozwój handlu internetowego i jego uwarunkowania perspektywa oferenta i nabywcy. Handel Wewnętrzny, 4, 110-120.

Gregor, B., Kalińska-Kula, M. (2018b). Zachowania e-nabywców dokonujących zakupów on-line i off-line. Handel Wewnętrzny, 6, 138-148.

https://www.gfk.com/uk-ua/rishennja/press-release/cci-apr-2018.

https://www.statista.com.

Internet Live Stats (2019). Retrieved from: https://www.internetlivestats.com/internet-users.

Internet World Stats (2019, June). Usage and Population Statistics. Retrieved from: https:// www.internetworldstats.com/stats.htm.

Jaciow, M., Wolny, R. (2011). Polski e-konsument. Typologia zachowania. Gliwice: One Press Helion.

Jasiński, J. (2016). Specyfika biznesu w internecie. In: M. Dutko (ed.), Biblia e-biznesu 2. Nowy Testament (pp. 27-32). Gliwice: One Press Helion.

Kieżel, E. (1995). Badania rynku a decyzje gospodarstw domowych. Katowice: Wydawnictwo Akademii Ekonomicznej w Krakowie.

Lewicki, M. (2018). E-handel w Polsce - stan i perspektywy rozwoju. Handel Wewnętrzny, 4 (375), $176-189$. 
Linkiewicz, A., Bartosik-Purgat, M. (2017). Konsument oraz proces decyzyjny w warunkach globalizacji. In: M. Bartosik-Purgat (ed.), Zachowania konsumentów. Globalizacja, nowe technologie, aktualne trendy, otoczenie społeczno-kulturowe (pp. 13-28). Warszawa: Wydawnictwo Naukowe PWN.

Lipsman, A. (2019). Global Ecommerce 2019. eMarketer. Retrieved from: https://www.emarketer.com/content/global-ecommerce-2019.

Malarska, A. (2005). Statystyczna analiza danych wspomagana programem SPSS. Kraków: Wydawca SPSS Polska Sp. z o.o.

Mynarski, S. (2003). Analiza danych rynkowych i marketingowych z wykorzystaniem programu Statistica. Kraków: Wydawnictwo Akademii Ekonomicznej w Krakowie.

Pacut, M. (2016). Zachowania nabywcze polskich e-konsumentów na rynku. Studia i Prace Wydziatu Nauk Ekonomicznych i Zarzadzania Uniwersytetu Szczecińskiego, 3 (43), 319-328. DOI: 10.18276/sip.2016.43/3-29.

Pires, G., Stanton, J., Eckford, A. (2004). Influences on the perceived risk of purchasing online. Journal of Consumer Behaviour, 4 (2), 118-131. DOI: 10.1002/cb.163.

Skorupska, J. (2017). E-commerce. Strategia, zarządzanie, finanse. Warszawa: Wydawnictwo Naukowe PWN.

Światowy, G. (2006). Zachowania konsumentów. Warszawa: Polskie Wydawnictwo Ekonomiczne.

Thomas, M.J. (1999). Podręcznik marketingu. Warszawa: Wydawnictwo Naukowe PWN.

We Are Social, HooteSuite (2020). Digital 2020 Global Overview Report. Retrieved from: https://wearesocial.com/digital-2020.

We Are Social, Hootsuite (2018). Digital 2018 Global Overview Report. Retrieved from: https:// wearesocial.com/blog/2018/01/global-digital-report-2018.

Wołoszyn, A., Stanisławska, J. (2016). Wybrane aspekty konsumpcji w polskich gospodarstwach domowych. Studia i Prace Wydziatu Nauk Ekonomicznych i Zarzadzania Uniwersytetu Szczecińskiego, 3 (43), 471-481. DOI: 10.18276/sip.2016.43/3-43.

Стратегия развития информатизаџии в Республике Беларусь на 2016-2022 годь (2015). Retrieved from: http:/e-gov.by/zakony-i-dokumenty/strategiya-razvitiya-informatizaciiv-respublike-belarus-na-2016-2022-gody.

Указ Президента Республики Беларусь 1 февраля 2010 г. № 60. О мерах по совершенствованию использования наџионального сегмента сети Интернет (2010). Retrieved from: https://drive.google.com/file/d/0ByeBjhaMgDpfcV9kai1jYXV5ZVE/view. 